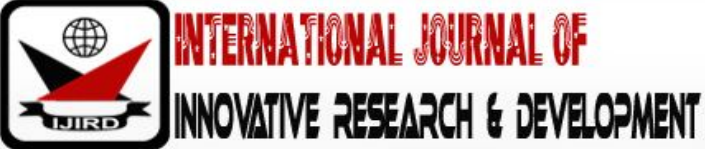

ISSN 2278 - 0211 (Online)

\section{Qualiity Standards and Inexpensive Drying Technology for Semi-Dried Jerky in Gialai Province: A Short Review}

Viet-Duc Ngo
Researcher, Department of Division of Computational Mechatronics, Institute for
Computational Science, Ton Duc Thang University, Ho Chi Minh City, Vietnam
Hoang-Thinh Do
Researcher, Department of Division of Computational Mechatronics, Institute for
Computational Science, Ton Duc Thang University, Ho Chi Minh City, Vietnam
Thuy-Van T. Duong
Director, Department of Center of Applied Information Technology,
Ton Duc Thang University, Ho Chi Minh City, Vietnam
Minh-Duc Tran
Researcher, Department of Division of Computational Mechatronics, Institute for
Computational Science, Ton Duc Thang University, Ho Chi Minh City, Vietnam
Sy-Dung Nguyen
Researcher, Department of Division of Computational Mechatronics, Institute for
Computational Science, Ton Duc Thang University, Ho Chi Minh City, Vietnam
Duy-Hien Tong
Researcher, Department of Division of Computational Mechatronics, Institute for
Computational Science, Ton Duc Thang University, Ho Chi Minh City, Vietnam
Thi-Bich-Hue Duong
Lecturer, Department of Environmental Science,
Vietnam National University Ho Chi Minh City, Vietnam

\begin{abstract}
:
The aims of this study were to: (1) review the quality standards for semi-dried jerky and (2) discuss common inexpensive drying methods as a preservation technique on nutrient contents of beef. A quality standard is a composite evaluation of factors that affect palatability of meat. These factors were materials, physicochemical evaluation, contaminated substances, bacteria, and parasites. Furthermore, the reviewed beef drying methods included natural drying, artificial drying and mixed mode solar drying. Results showed that solar greenhouse drying system is the optimal technique that could apply for semi-dried jerky in Gia Lai province. This study presents a brief overview of literature and legal resources related to food quality and inexpensive drying methods that would be suitable for semidried jerky in Gialai province.
\end{abstract}

Keywords: Drying technology, quality standards, semi-dried jerky, solar greenhouse drying

\section{Introduction}

Jerky is one of the typical intermediate-moisture foods that has been cut into strips and dried (dehydrated) to prevent spoilage [1]. Before dehydrating process, salt is usually added to prevent bacteria growth. Modern manufactured jerky is often marinated, prepared with a seasoned spice rub or liquid, or smoked with low heat (usually under $70^{\circ} \mathrm{C}$ ). Store-bought jerky commonly includes sweeteners such as brown sugar [2].

The drying process is the oldest and widely used preservation methods of foods due to highly efficient and inexpensive. The shelf-life of meat and meat products were extended because of the reduction in water activity $[3,4]$. The microbial load was reduced after the drying process and volumes and weights of the products were also lighter, which decrease storage and transportation costs [5].

Semi-dried jerky is a famous product in Gialai province because its properties from beef meat, specialty, featured spice... However, a major problem associate with this product is that we have no appropriate techniques of meat preservation that are suitable for Gialai. The meat is smoked and dried mainly by the village human who are mostly illiterate and have no scientific knowledge about its quality [6, 7]. Obviously, their products do not meet the quality standards. There is no information on the physical and nutritional features of drying of beef in Gialai. Furthermore, 
selecting the correct drying method is important step affecting the quality, time, and cost of dried food products. Therefore, the application and advances of different drying methods need to be considered.

This research is a part of a project that investigates the quality and develops a new solar dryer for semi-dried jerky in Gialai province.

This study reviewed (1) the present quality standards published by Vietnam Standards and Quality Institute (VSQI); (2) discuss some common drying methods that are suitable for semi-dried jerky. The considering methods were natural drying, artificial drying and mixed mode solar drying

\section{Quality Standards for Semi-Dried Jerky}

\subsection{Definitions}

Beef standards and grading are terms that require some definition for accurate discussion as, together with classification, they are often used interchangeably in discussing beef appearance, cuts, estimated yield and eating quality. Classification is defined as a set of descriptive terms describing features of beef that are useful to those involved in the trading. Generally, this involves ranking beef in a hierarchy for the traits of interest. Depending upon the country marbling and lean color and/ or texture have often been included other measurements of fatness (internal fat scores, rib) or muscling (eye muscle area, or carcass conformation). These parameters remain relevant and are in use today in most beef grading schemes [8]. Although the standard and quality grades for beef has been published by government in most countries in the world, related report on semi-dried jerky is limited. Vietnam standards are based on nationally uniform standards of quality developed by VSQI. VSQI published that the standards for fresh meat are following TCVN 7046:2009 [9]. Before treating with sun drying, beef was mixed with food additives such as salt, sugar, pepper, chili, lemongrass, monosodium glutamate. Therefore, TCVN 9668:2017 for corned beef has been reviewed [10]. Although semi-dried jerky in Gialai has been treated by natural sun drying method, the rest part is dominant ( $>5 \%)$ which has not yet treated by sun drying. Therefore, TCVN 9668:2017 is not suitable for semi-dried jerky. Additionally, the product was stored in cool or frozen condition after drying and packaging. The product should be applied the standard for frozen meat. Thus, TCVN 7047:2009 for frozen meat was reviewed [11].

\section{Standards Review for Semi-Dried Jerky}

\subsection{Materials}

Fresh meat from the cattle has to approve by the competent veterinary inspection agency for use as food.

3.2. Sensory Evaluation

\begin{tabular}{|c|c|}
\hline Properties & Requirements \\
\hline \multirow{4}{*}{ Visual observation } & The meat surface is dry, clean, free from fur and impurity \\
\cline { 2 - 2 } & Smooth shear \\
\cline { 2 - 2 } & Elasticity, no fingerprint when pressing \\
\cline { 2 - 2 } & The marrow adheres to the medullary tube (option) \\
\hline Color & Product feature \\
\hline Smell & Product feature, no funky smell \\
\hline Flavor & Product feature \\
\hline
\end{tabular}

Table 1. Sensory Evaluation

3.3. Physicochemical Evaluation

\begin{tabular}{|c|c|}
\hline Properties & Requirement \\
\hline $\mathrm{pH}$ & $5.5 \sim 6.2$ \\
\hline Qualitative reaction with hydro sulfua $\left(\mathrm{H}_{2} \mathrm{~S}\right)$ & Negative \\
\hline Ammonia content, $(\mathrm{mg} / 100 \mathrm{~g})$ & $\leq 35$ \\
\cline { 2 - 2 }
\end{tabular}

Table 2: Physicochemical Evaluation

\subsection{Contaminated substances}

\subsubsection{Heavy Metal Content}

\begin{tabular}{|c|c|}
\hline Properties & Maximum (mg/ kg) \\
\hline Cadimi $(\mathrm{Cd})$ & 0.05 \\
\hline Lead $(\mathrm{Pb})$ & 0.1 \\
\hline
\end{tabular}

Table 3: Heavy Metal Content 


\subsubsection{Hormone Residue}

\begin{tabular}{|c|c|}
\hline Properties & Maximum (mg/ kg) \\
\hline Dietylstylbestrol & 0,0 \\
\hline Testosterol & 0,015 \\
\hline Estadiol & 0,0005 \\
\hline Beta-agonist group (Salbutanol and Clenbutanol) & Disallow \\
\hline
\end{tabular}

Table 4: Hormone Residue

\subsubsection{Veterinary Drug Residue and Pesticide Residue}

Veterinary drug is following 24/2013/ TT-BYT circular (Appendix A) while pesticide residue is according to the 50/ 2016/ TT-BYT circular (Appendix B) [12, 13].

\subsection{Bacteria}

\begin{tabular}{|c|c|}
\hline Properties & Maximum (Colony forming unit CFU/ g) \\
\hline Aerobic bacteria & $10^{5}$ \\
\hline Coliform & $10^{2}$ \\
\hline E. coli & $10^{2}$ \\
\hline Staphytlococcus aureus & $10^{2}$ \\
\hline Clostridium perfringens & $10^{2}$ \\
\hline Salmonella (in 25g product) & Disallow \\
\hline
\end{tabular}

Table 5: Bacteria

3.6. Parasites

\begin{tabular}{|c|c|}
\hline Properties & Requirement \\
\hline Cysticercus csuitsae; Cysticercus bovis... & Disallow \\
\hline Trichinella spiralis & \\
\hline
\end{tabular}

Table 6: Parasites

\section{Drying Technology}

\subsection{Definitions}

Drying is the oldest method of preserving food. Drying is applied to reduce the water content of products. Reducing the water content of products is purpose to prolong the shelf-life of bio-origin by reducing the water activity. At low water content, growth of microorganisms, enzymatic reactions, and other deteriorative reactions are inhibited [14, $15]$.

Basically, drying can be divided into two types: natural drying and artificial drying. Natural drying takes place under the influence of sunlight and wind. There is no control over temperature, air flow and humidity in natural drying. Artificial drying is the method which can control the condition of drying process. Artificial drying includes the methods drying by heated air, direct contact with heated surface, and application of energy from a radiating microwave or dielectric source [15-20].

\subsection{Natural Drying}

\subsubsection{Sun Drying:}

Drying the food product under natural sunny conditions is called as sun drying. This drying process is no required energy. Hot days are desirable with high temperature $\left(\geq 35^{\circ} \mathrm{C}\right)$ and low humidity. However, problems of contamination and intermittent drying are generally encountered with sun drying. For sun drying, vegetables and meats are not recommended. Microorganism in meats will grow due to high protein when heat and humidity cannot be controlled [2125]. 


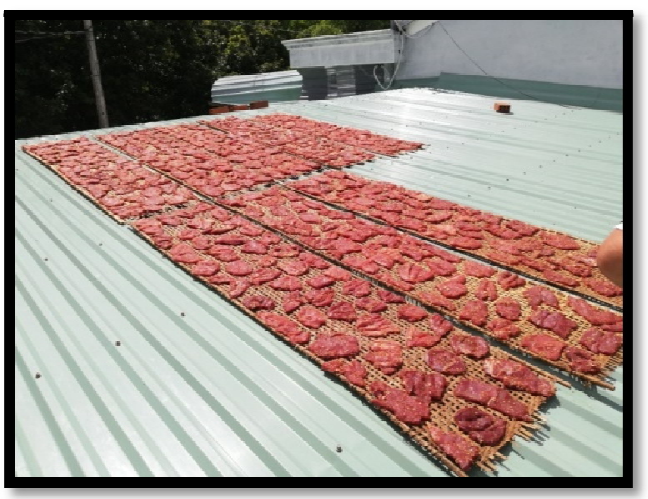

Figure 1: Sun Drying Beef

\begin{tabular}{|c|c|}
\hline Advantages & Disadvantages \\
\hline No energy is required & Slow drying process \\
\hline Cheap, simple & Time taking \\
\hline Friendly to the environment & Molding of food may occur due to slow drying \\
\hline & Cannot carried out in dust, rainy weather \\
\hline & Contaminations from the environment \\
\hline & Product losses and contaminations by insects and birds \\
\hline & Floor space requirements \\
\hline & Inconsistent sensory quality \\
\hline
\end{tabular}

Table 7: Advantages and Disadvantages of Sun Drying

\subsection{Solar Drying}

Solar drying also uses the sun as the heat source. It uses designed structures to collect and enhance solar radiation. There are two types of solar dryer [26, 27]:

+Direct solar dryer: expose the substance to be dehydrated to direct sunlight.

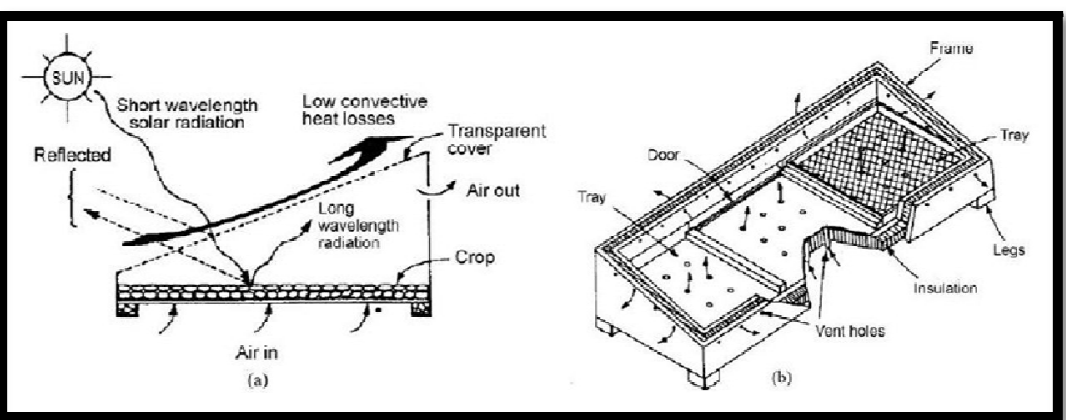

Figure 2: Working Principle of Direct Solar Dryer [28]

+ Indirect solar dryer: the sun shines upon a solar collector heating air which then moves upward through a stack of four to six trays loaded with produce. Indirect solar dryer is ideal for small scale due to low cost requirements and low throughput whereas the commercial drying requires high throughput

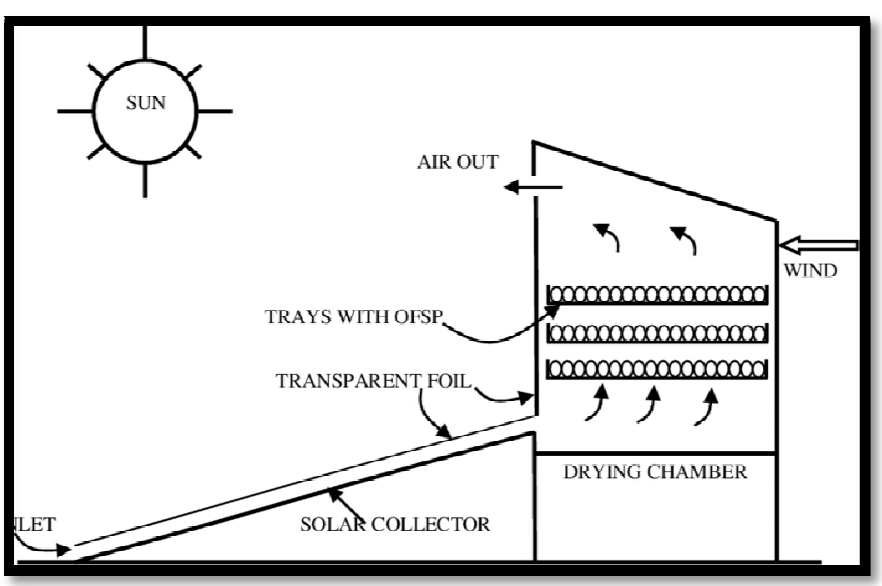

Figure 3: Indirect Solar Dryer [29] 
Solar dryers consist of three main components: a drying chamber in which food is dried, a solar collector that heats the air, and airflow system. The drying chamber could protect the food from insects, dust, rain, and animals. The solar collector is made by a dark or black colored box with a transparent cover. The solar collector can heat the air temperature within $10 \sim 30^{\circ} \mathrm{C}$ above ambient temperature. The airflow system can be natural convection or forced convection with fans. The forced convection can reduce the drying time and increase drying efficiency [29, 30]. The advantages and disadvantages of solar drying method are shown in Table 8 [31].

\begin{tabular}{|c|c|}
\hline Advantages & Disadvantages \\
\hline $\begin{array}{c}\text { Drying is faster because inside the dryer it is } \\
\text { warmer than outside }\end{array}$ & UV radiation can damage food \\
\hline Less risk of spoilage & More complex and expensive than direct sun drying \\
\hline $\begin{array}{c}\text { The product is protected against flies, pests, rain } \\
\text { and dust }\end{array}$ & Capacity per unit area of dryer is limited \\
\hline Labour saving & \\
\hline $\begin{array}{c}\text { The quality of the product is better in terms of } \\
\text { nutrients, hygiene and colour }\end{array}$ & \\
\hline
\end{tabular}

Table 8: Advantages and Disadvantages of Solar Drying

\section{Artificial Drying}

\subsection{Oven Drying}

Air-oven drying is one of the most widely and commonly used methods. An oven is commonly combined the factors of heat, low humidity and air flow. The ovens should be thermally regulated to $\pm 0.5^{\circ} \mathrm{C}$ and have minimal temperature variations $\left(\leq 3^{\circ} \mathrm{C}\right.$ is better). The heat source is usually electric or infrared.

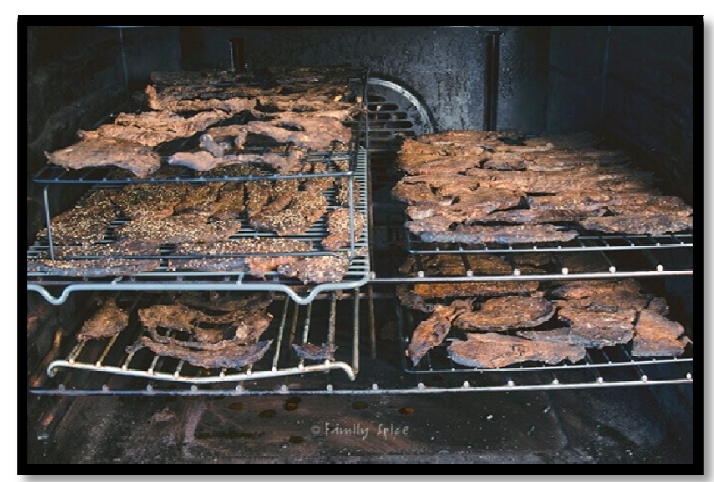

Figure 4: Beef Jerky in Oven Dryer

There is no temperature control feature for lowering the heat and the oven usually run at high temperature. Infrared is usually the best choice where a process requires high temperature and a lower capital expense. Infrared radiation causes rapid and direct heat concentration on the material compared to the electrical heat source [32, 33].

\begin{tabular}{|c|c|}
\hline Advantages & Disadvantages \\
\hline Accommodates large number of samples & $\begin{array}{c}\text { Variations of temperature due to particle size, } \\
\text { sample weight, position in the oven }\end{array}$ \\
\hline Large sample volumes possible & Difficult to remove all water \\
\hline High accuracy & Loss of volatile substances during drying \\
\hline Attain the desired temperature more rapidly & Decomposition of sample (i.e., sugar) \\
\hline
\end{tabular}

Table 9: Advantages and Disadvantages of Oven Drying

\subsection{Freeze Drying}

Freeze drying is a low temperature dehydration process that involves freezing the food, the reducing the pressure and adding heat to allow the frozen water in the food to sublimate. Freeze drying occurs in three phases. 


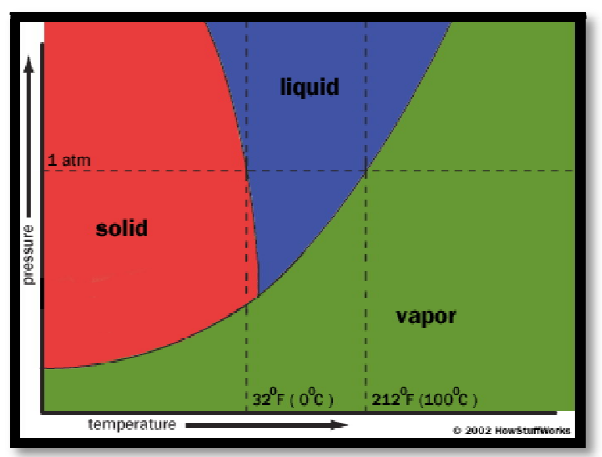

Figure 5: Phrase Diagram [34]

- Freeze phase: during the freeze phase, food is cooled below its triple point, the lowest temperature at which the solid, liquid and vapor phases of the food can coexist.

- Primary drying phase (sublimation): during the primary drying phase, the pressure is lowered and heat is added to the food in order for the water to sublimate. The structure of food could be altered if too much heat is added. About $95 \%$ of the water is sublimated.

- Secondary drying phase (adsorption): the final phase is secondary drying, during which the ionically-bound water molecules are removed. The temperature is raised higher than in the primary drying phase to break the bonds between food and water molecules.

\begin{tabular}{|c|c|}
\hline Advantages & Disadvantages \\
\hline Shelf-life extension & $\begin{array}{c}\text { Spoilage organisms and pathogens resistant to the low } \\
\text { temperature dehydration process can remain }\end{array}$ \\
\hline $\begin{array}{c}\text { Nutrients are retained and } \\
\text { color is maintained }\end{array}$ & High cost \\
\hline Easy storage & The product is prone to oxidation, due to high porosity and large \\
surface area
\end{tabular}

Table 10: Advantages and Disadvantages of Freeze Drying

\section{Mixed Mode Solar Drying}

\subsection{Passive Mode}

The passive mode solar dryer is due to natural circulation. It is similar with indirect solar dryer. However, to minimize heat losses from the back of the solar collector, an insulation layer is installed at the bottom of the collector.

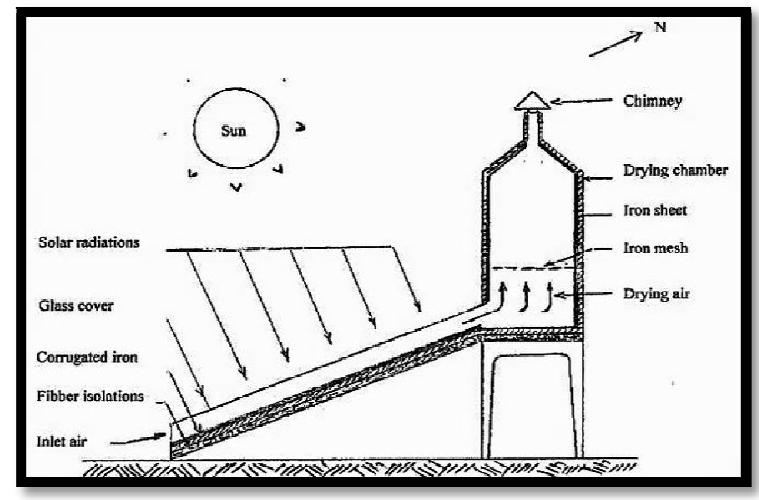

Figure 6: Passive Solar Dryer [35]

\subsection{Active Mode}

In this mode of mixed solar dryers, a blower or fan is installed to force the air into or out of the drying chamber. Solar dryer with green house is commonly used. Green house made from glass, plastic film, poly film or polycarbonate plate is often used as a collector. Heat air is forced to pass through the drying trays with an exhaust fan. 


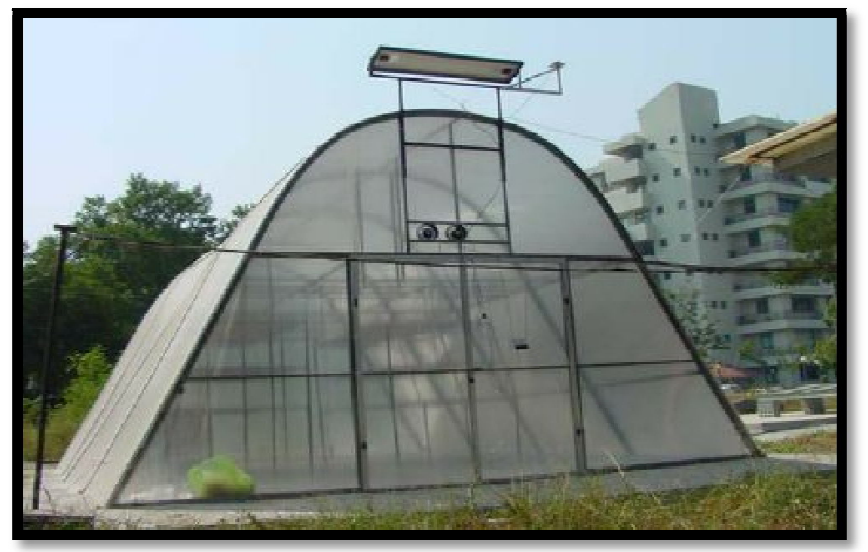

Figure 7: Active Solar Dryer [36]

\section{Conclusions}

This paper discussed various types of drying methodologies. Among the advantages of a greenhouse dryer are simple structure, large load capacity and relatively good thermal performance. We concluded that greenhouse dryer is most suited for semi-dried jerky in Gialai province, Vietnam.

Furthermore, standardization is an important criterion for assessing the progress made by Vietnam in the integration process to the worldwide. Although the compliance with standards is not mandatory (the standards are not laws but rules, guidelines and characteristics for activities and their results), we hope that the products "in compliance" have the best quality while delivering to the consumers.

\section{Acknowledgement}

This research is funded by People's Committee of Gia Lai province under grant number KHGL-02-18. This work was supported by Gialai Department of Science and Technology, and Ton Duc Thang University, Ho Chi Minh City, Vietnam.

\section{References}

i. $\quad$ Kim, G.-D., Jung, E.-Y., Seo, H.-W., Joo, S.-T., \& Yang, H.-S. (2010). Textural and Sensory Properties of Pork Jerky Adjusted with Tenderizers or Humectant. Korean Journal for Food Science of Animal Resources, 30(6), 930-937. https:/ / doi.org/ 10.5851/ kosfa.2010.30.6.930

ii. Han, D.-J., Choi, J.-H., Choi, Y.-S., Kim, H.-Y., Kim, S.-Y., Kim, H.-W., Chung, H.-K., \& Kim, C.-J. (2011). Effects of Konjac, Isolated Soy Protein, and Egg Albumin on Quality Properties of Semi-dried Chicken Jerky. Korean Journal for Food Science of Animal Resources, 31(2), 183-190. https:/ / doi.org/ 10.5851/ kosfa.2011.31.2.183

iii. Modi, V. K, Sachindra, N. M., Nagegowda, P., Mahendrakar, N. S., \& Narasimha Rao, D. (2007). Quality changes during the storage of dehydrated chicken kebab mix. International Journal of Food Science \& Technology, 42(7), 827-835. https:/ / doi.org/ 10.1111/j.1365-2621.2007.01291.x

iv. Aksoy, A., Karasu, S., Akcicek, A., \& Kayacan, S. (2019). Effects of Different Drying Methods on Drying Kinetics, Microstructure, Color, and the Rehydration Ratio of Minced Meat. Foods, 8(6), 216. https:/ / doi.org/ 10.3390/ foods8060216

v. Doymaz, İ., Karasu, S., \& Baslar, M. (2016). Effects of infrared heating on drying kinetics, antioxidant activity, phenolic content, and color of jujube fruit. Journal of Food Measurement and Characterization, 10(2), 283-291. https:/ / doi.org/ 10.1007/ s11694-016-9305-4

vi. Phuong Vi. (2019). Vuon xa thuong hieu bo mot nang. https:/ / www.baogialai.com.vn/ channel/ 12400/ 201903/ vuon-xa-thuong-hieu-bo-mot-nang-5624251/

vii. Anh Phuong. (2015). Bo mot nang va muoi kien vang doc dao o Gia Lai. https:// vnexpress.net/ bo-mot-nang-vamuoi-kien-vang-doc-dao-o-gia-lai-3329838.html

viii. Polkinghorne, R. J., \& Thompson, J. M. (2010). Meat standards and grading. Meat Science, 86(1), 227-235. https:/ / doi.org/ 10.1016/ j.meatsci.2010.05.010

ix. TCVN 7046:2009. Fresh meat - technical requirements. https:// luatvietnam.vn/ nong-nghiep/ tieu-chuan-tcvn7046-2009-yeu-cau-ky-thuat-ve-thit-tuoi-166791-d3.html

x. TCVN 9668:2017. Corned beef. https:// luatvietnam.vn/ thuc-pham/ tieu-chuan-tcvn-9668-2017-thit-bo-da-xuly-nhiet-165313-d3.html

xi. TCVN 7047:2009. Frozen meat - technical requirements. https:/ / luatvietnam.vn/ thuc-pham/ tieu-chuan-tcvn7047-2009-yeu-cau-ky-thuat-voi-thit-dong-lanh-166792-d3.html

xii. 50/2016/TT-BYT. Thong tu quy dinh gioi han toi da du luong thuoc bao ve thuc vat trong thuc pham. https:/ / luatvietnam.vn/ y-te/ thong-tu-50-2016-tt-byt-bo-y-te-111845-d1.html

xiii. 24/2013/TT-BYT. Thong tu ban hanh "Quy dinh muc gioi han toi da du luong thuoc thu y trong thuc pham". https:/ / luatvietnam.vn/ y-te/ thong-tu-24-2013-tt-byt-bo-y-te-80644-d1.html

xiv. Mujumdar, A. S., \& Law, C. L. (2010). Drying Technology: Trends and Applications in Postharvest Processing. Food and Bioprocess Technology, 3(6), 843-852. https:// doi.org/ 10.1007/ s11947-010-0353-1

xv. Ahmed, N., Singh, J., Chauhan, H., \& Anjum, P. G. A. (2013). Different Drying Methods: Their Applications and 
Recent Advances. 10.

xvi. Huang, L., Zhang, M., Mujumdar, A. S., \& Lim, R. (2011). Comparison of four drying methods for re-structured mixed potato with apple chips. Journal of Food Engineering, 103(3), 279-284. https:/ / doi.org/ 10.1016/j.jfoodeng.2010.10.025

xvii. Artnaseaw, A., Theerakulpisut, S., \& Benjapiyaporn, C. (2010). Development of a vacuum heat pump dryer for drying chilli. Biosystems Engineering, 105(1), 130-138. https:/ / doi.org/ 10.1016/j.biosystemseng.2009.10.003

xviii. Askari, G. R., Emam-Djomeh, Z., \& Mousavi, S. M. (2009). An Investigation of the Effects of Drying Methods and Conditions on Drying Characteristics and Quality Attributes of Agricultural Products during Hot Air and Hot Air/ Microwave-Assisted Dehydration. Drying Technology, 27(7-8), 831-841.

https:/ / doi.org/ 10.1080/ 07373930902988106

xix. Fernandes, F. A. N., Rodrigues, S., Law, C. L., \& Mujumdar, A. S. (2011). Drying of Exotic Tropical Fruits: A Comprehensive Review. Food and Bioprocess Technology, 4(2), 163-185. https:// doi.org/ 10.1007/ s11947010-0323-7

xx. Giri, S. K., \& Prasad, S. (2007). Drying kinetics and rehydration characteristics of microwave-vacuum and convective hot-air dried mushrooms. Journal of Food Engineering, 78(2), 512-521.

https:/ / doi.org/ 10.1016/j.jfoodeng.2005.10.021

xxi. Toğrul, İ. T., \& Pehlivan, D. (2004). Modelling of thin layer drying kinetics of some fruits under open-air sun drying process. Journal of Food Engineering, 65(3), 413-425. https:/ / doi.org/ 10.1016/ j.jfoodeng.2004.02.001

xxii. Doymaz, I. (2005). Sun drying of figs: An experimental study.Journal of Food Engineering, 71(4), 403-407. https:/ / doi.org/ 10.1016/j.jfoodeng.2004.11.003

xxiii. Jain, D., \& Pathare, P. B. (2007). Study the drying kinetics of open sun drying of fish. Journal of Food Engineering, 78(4), 1315-1319. https:/ / doi.org/ 10.1016/j.jfoodeng.2005.12.044

xxiv. Doymaz, İ. (2004). Pretreatment effect on sun drying of mulberry fruits (Morus alba L.). Journal of Food Engineering, 65(2), 205-209. https:/ / doi.org/ 10.1016/j.jfoodeng.2004.01.016

xxv. Purohit, P., Kumar, A., \& Kandpal, T. C. (2006). Solar drying vs. open sun drying: A framework for financial evaluation. Solar Energy, 80(12), 1568-1579. https:/ / doi.org/ 10.1016/ j.solener.2005.12.009

xxvi. Belessiotis, V., \& Delyannis, E. (2011). Solar drying. Solar Energy, 85(8), 1665-1691. https:// doi.org/ 10.1016/ j.solener.2009.10.001

xxvii. Akpinar, E. K. (2010). Drying of mint leaves in a solar dryer and under open sun: Modelling, performance analyses. Energy Conversion and Management, 51(12), 2407-2418.

https:/ / doi.org/ 10.1016/ j.enconman.2010.05.005

xxviii. Sadeghi, G., Taheri, O., \& Mobadersani, F. $(2012,20)$. NEW TECHNOLOGIES OF SOLAR DRYING SYSTEMS FOR AGRICULTURAL AND MARINE PRODUCTS. The 1st Middle-East Drying Conference (MEDC2012), Iran.

xxix. Orodi Odhiambo. (2015). Greenhouse Solar Dryers. https:/ / doi.org/ 10.13140/ RG.2.1.1142.6643

xxx. Ekechukwu, O. V., \& Norton, B. (1999). Review of solar-energy drying systems II: An overview of solar drying technology. Energy Conversion and Management, 40(6), 615-655. https:// doi.org/ 10.1016/ S01968904(98)00093-4

xxxi. Advantages and disadvantages of the solar drying of sewage sludge in Poland. (2017). Czasopismo Techniczne, 12. https:// doi.org/ 10.4467/2353737XCT.17.217.7760

xxxii. Inyang, U., Oboh, I., \& Etuk, B. (2017). Drying and the Different Techniques. International Journal of Food Nutrition and Safety, 8(1), 45-72.

xxxiii. Ahn, J. Y., Kil, D. Y., Kong, C., \& Kim, B. G. (2014). Comparison of Oven-drying Methods for Determination of Moisture Content in Feed Ingredients. Asian-Australasian Journal of Animal Sciences, 27(11), 1615-1622. https:/ / doi.org/ 10.5713/ ajas.2014.14305

xxxiv. Shukla, S. (n.d.). FREEZE DRYING PROCESS: A REVIEW. 2 , 8.

xxxv. Mourad, R. (2011). Passive Solar Drying of Loquat (Eriobotrya Japonica) Fruit Slices. Alexandria Journal of Food Science and Technology, 8, 25-30.

xxxvi. Mohsin, A. S. M., Maruf, Md. N. I., Sayem, A. H. M., Mojumdar, Md. R. R., \& Shamim Farhad, H. M. (2011). Prospect \& Future of Solar Dryer: Perspective Bangladesh. International Journal of Engineering and Technology, 3(2), 165-170. https:/ / doi.org/ 10.7763/ IJET.2011.V3.217 


\section{Appendix}

\begin{tabular}{|c|c|c|c|c|}
\hline No. & Property & $\begin{array}{c}\text { ADI (pg/ kg } \\
\text { Bodyweight/ Day) }\end{array}$ & Ingredients & $\begin{array}{c}\text { MRL } \\
(\mu g / \mathrm{kg})\end{array}$ \\
\hline 1 & $\begin{array}{c}\text { Albendazole } \\
\text { (Anthelmintic) }\end{array}$ & $0-50$ & $\begin{array}{l}\text { 2-aminosulfone } \\
\text { metabolite }\end{array}$ & 100 \\
\hline 2 & $\begin{array}{c}\text { Amoxicillin } \\
\text { (Antibacterial drug) }\end{array}$ & $0-0.07$ & Amoxicillin & 50 \\
\hline 3 & $\begin{array}{c}\text { Benzylpenicillin } \\
\text { Procaine benzylpenicillin } \\
\text { (Antibacterial drug) }\end{array}$ & 30 & Benzylpenicillin & 50 \\
\hline 4 & $\begin{array}{c}\text { Ceftiofur } \\
\text { (Antibacterial drug) }\end{array}$ & $0-50$ & Desfuroylceftiofur & 1000 \\
\hline 5 & $\begin{array}{l}\text { Chlortetracycline } \\
\text { Oxytetracycline } \\
\text { Tetracycline } \\
\text { (Antibacterial drug) }\end{array}$ & $0-30$ & $\begin{array}{l}\text { Main ingredients, } \\
\text { individual ingredient } \\
\text { and combined } \\
\text { ingredient }\end{array}$ & 200 \\
\hline 6 & $\begin{array}{l}\text { Clenbuterol } \\
\text { (Sympathomimetic drugs - } \\
\text { adrenoceptor) }\end{array}$ & $0-0.004$ & Clenbuterol & 0.2 \\
\hline 7 & $\begin{array}{c}\text { Closantel } \\
\text { (Anthelmintic) }\end{array}$ & $0-30$ & Closantel & 1000 \\
\hline 8 & $\begin{array}{c}\text { Colistin } \\
\text { (Antibacterial drug) }\end{array}$ & $0-7$ & $\begin{array}{c}\text { Total Colistin A and } \\
\text { Colistin B }\end{array}$ & 150 \\
\hline 9 & $\begin{array}{l}\text { Cyfluthrin } \\
\text { (Insecticide) }\end{array}$ & $0-20$ & Cyfluthrin & 20 \\
\hline 10 & $\begin{array}{l}\text { Cyhalothrin } \\
\text { (Insecticide) }\end{array}$ & $0-5$ & Cyhalothrin & 20 \\
\hline 11 & $\begin{array}{l}\text { Cypermethrin } \\
\text { Alpha-cypermethrin } \\
\text { (Insecticide) }\end{array}$ & $0-20$ & $\begin{array}{l}\text { Total cypermethrin } \\
\text { residual }\end{array}$ & 50 \\
\hline 12 & $\begin{array}{c}\text { Danofloxacin } \\
\text { (Antibacterial drug) }\end{array}$ & $0-20$ & Danofloxacin & 200 \\
\hline 13 & $\begin{array}{c}\text { Deltamethrin } \\
\text { (Insecticide) }\end{array}$ & $0-10$ & Deltamethrin & 30 \\
\hline 14 & $\begin{array}{c}\text { Dexamethasone } \\
\text { (Glucocorticosteroid) }\end{array}$ & $0-0.015$ & Dexamethasone & 1 \\
\hline 15 & $\begin{array}{l}\text { Dihydrostreptomycin } \\
\text { Streptomycin } \\
\text { (Antibacterial drug) }\end{array}$ & $0-50$ & $\begin{array}{c}\text { Sum of } \\
\text { dihydrostreptomycin } \\
\text { and streptomycin }\end{array}$ & 600 \\
\hline 16 & $\begin{array}{c}\text { Diminazene } \\
\text { (Drug treatment of blood } \\
\text { parasites) }\end{array}$ & $0-100$ & Diminazene & 500 \\
\hline 17 & $\begin{array}{c}\text { Doramectin } \\
\text { (Anthelmintic) }\end{array}$ & $0-1$ & Doramectin & 10 \\
\hline 18 & $\begin{array}{l}\text { Eprinomectin } \\
\text { (Anthelmintic) }\end{array}$ & $0-10$ & Eprinomectin B1a & 100 \\
\hline 19 & $\begin{array}{c}\text { Febantel } \\
\text { Fenbendazole } \\
\text { Oxfendazole } \\
\text { (Anthelmintic) }\end{array}$ & $0-7$ & $\begin{array}{l}\text { Sum of fenbendazole, } \\
\text { oxfendazole and } \\
\text { oxfendazole sulphone }\end{array}$ & 100 \\
\hline 20 & $\begin{array}{l}\text { Fluazuron } \\
\text { (Insecticide) }\end{array}$ & $0-40$ & Fluazuron & 200 \\
\hline 21 & $\begin{array}{c}\text { Flumequine } \\
\text { (Antibacterial drug) }\end{array}$ & $0-30$ & Flumequine & 500 \\
\hline 22 & $\begin{array}{c}\text { Gentamicin } \\
\text { (Antibacterial drug) }\end{array}$ & $0-20$ & Gentamicin & 100 \\
\hline 23 & $\begin{array}{c}\text { Isometamidium } \\
\text { (Drug treatment of blood } \\
\text { parasites) }\end{array}$ & $0-100$ & Isometamidium & 100 \\
\hline 24 & $\begin{array}{c}\text { Levamisole } \\
\text { (Anthelmintic) }\end{array}$ & $0-6$ & Levamisole & 10 \\
\hline
\end{tabular}




\begin{tabular}{|c|c|c|c|c|}
\hline No. & Property & $\begin{array}{c}\text { ADI (pg/ kg } \\
\text { Bodyweight/ Day) }\end{array}$ & Ingredients & $\begin{array}{c}\text { MRL } \\
(\mu g / \mathrm{kg})\end{array}$ \\
\hline 25 & $\begin{array}{c}\text { Monensin } \\
\text { (Antibacterial drug) }\end{array}$ & $0-10$ & Monensin & 10 \\
\hline 26 & $\begin{array}{c}\text { Moxidectin } \\
\text { (Anthelmintic) }\end{array}$ & $0-2$ & Moxidectin & 20 \\
\hline 27 & $\begin{array}{c}\text { Narasin } \\
\text { (Antibacterial drug) }\end{array}$ & $0-5$ & Narasin A & 15 \\
\hline 28 & $\begin{array}{c}\text { Neomycin } \\
\text { (Antibacterial drug) }\end{array}$ & $0-60$ & Neomycin & 500 \\
\hline 29 & $\begin{array}{c}\text { Pirlimycin } \\
\text { (Antibacterial drug) }\end{array}$ & $0-8$ & Pirlimycin & 100 \\
\hline 30 & $\begin{array}{c}\text { Ractopamine } \\
\text { (Growth stimulant drugs) }\end{array}$ & $0-1$ & Ractopamine & 10 \\
\hline 31 & $\begin{array}{c}\text { Spectinomycin } \\
\text { (Antibacterial drug) }\end{array}$ & $0-40$ & Spectinomycin & 500 \\
\hline 32 & $\begin{array}{c}\text { Spiramycin } \\
\text { (Antibacterial drug) }\end{array}$ & $0-50$ & $\begin{array}{l}\text { Sum of spiramycin } \\
\text { and neospiramycin }\end{array}$ & 200 \\
\hline 33 & $\begin{array}{l}\text { Thiabendazole } \\
\text { (Anthelmintic) }\end{array}$ & $0-100$ & $\begin{array}{l}\text { Sum of thiabendazole } \\
\text { and 5- } \\
\text { hydroxythiabendazole }\end{array}$ & 100 \\
\hline 34 & $\begin{array}{c}\text { Tilmicosin } \\
\text { (Antibacterial drug) }\end{array}$ & $0-40$ & Tilmicosin & 100 \\
\hline 35 & $\begin{array}{c}\text { Trenbolone acetate } \\
\text { (Growth stimulant drugs) }\end{array}$ & $0-0.02$ & Beta-trenbolone & 2 \\
\hline 36 & $\begin{array}{l}\text { Triclabendazole } \\
\text { (Anthelmintic) }\end{array}$ & $0-3$ & Ketotriclabendazole & 250 \\
\hline 37 & $\begin{array}{c}\text { Tylosin } \\
\text { (Antibacterial drug) }\end{array}$ & $0-30$ & Tylosin A & 100 \\
\hline 38 & $\begin{array}{c}\text { Zeranol } \\
\text { (Growth stimulant drugs) }\end{array}$ & $0-0.5$ & Zeranol & 2 \\
\hline
\end{tabular}

Table 11: Maximum Veterinary Drug in Beef Meat 